Dikumpulkan : 31 Juli 2017

Direvisi : 25 Agustus 2017

Diterima : 28 September 2017

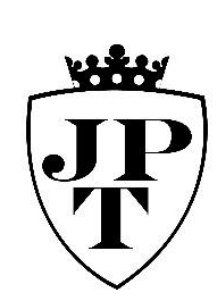

\title{
Paket Wisata Bagi Difabel Di Yogyakarta
}

\author{
FEBRI HANDOYO, AUFI NIDAU SHOLIHAH, ANGGIT NOVITARIASARI, ASHILA \\ FITRA HANI, QONITA PUTRI FIRDAUSA, HANDAYANI RAHAYUNINGSIH \\ Universitas Gadjah Mada \\ febri.handoyo@mail.ugm.ac.id,aufi.nidau.sholihah@mail.ugm.ac.id, \\ anggit.n@mail.ugm.ac.id, ashila.fitra.hani@mail.ugm.ac,qonita.p@mail.ugm.ac.id, \\ handayani.rahayuningsih@ugm.ac.id
}

\begin{abstract}
Yogyakarta is the one of the biggest tourist destination in Indonesia. Domestic and Foreigner tourist come to this city every year in big number. Yogyakarta has so many tourist destinations, for example: Keraon Yogyakarta, Sambisari Temple, Taman Pintar, Malioboro, etc. Because of that, Yogyakarta need travel agents to makes every tourist easier enjoy their trip, and the number of travel agents in Yogyakarta has growth every year. Tourist who come to Yogyakarta is not only normal people, but also people with disability, they also have same chance to do tourism activity and travel agents should accommodate it. The purpose of the research is to know how far the travel agents in Special Region of Yogyakarta can create tour package for people with disabilities. The research also explained about how many local tourists and international tourists who come to Yogyakarta every year. From that data, we know how many markets for tour package in Yogyakarta. The methods used in the research is qualitative method. The writers collected the data by interview, literature study, and observation. The subject of the interview is people with disability, government, and the management of the tourism destination. The writers also compare the result from the interview with the fact in the field. From the result of the research the writers can conclude tour package that has been offered by travel agents in Yogyakarta is not friendly for people with disabilities.
\end{abstract}

Keywords:

travel agent, tour package, people with disabillity, Yogyakarta 


\section{Pendahuluan}

Yogyakarta selain dikenal sebagai kota perjuangan, kebudayaan dan pendidikan, juga dikenal dengan kekayaan sumber daya alam dan budayanya. Sampai sekarang Yogyakarta masih menjadi kota yang menjadi tujuan wisata terkemuka bagi wisatawan domestik dan juga mancanegara. Yogyakarta menjadi daerah wisata terkemuka karena telah tersedianya sarana dan prasarana sebagai penunjang kepariwisataan, seperti akomodasi, restoran/rumah makan, telekomunikasi, tempat hiburan dan lain-lain (Badan Pusat Statistik, 2015). Yogyakarta juga dikenal dengan kearifan masyarakatnya, setiap wisatawan yang datang ke Yogyakarta akan dijamu dengan keramah-tamahan, dan kehangatannya. Wisatawan yang berkunjung ke Yogyakarta tidak hanya wisatawan normal, namun juga didalamnya ada wisatawan dengan kebutuhan khusus atau disabilitas.

Menurut Undang-Undang Nomor 8 Tahun 2016 penyandang disabilitas adalah setiap orang yang mengalami keterbatasan fisik, intelektual, mental, dan/atau sensorik dalam jangka waktu lama yang dalam berinteraksi dengan lingkungan dapat mengalami hambatan dan kesulitan untuk berpartisipasi secara penuh dan efektif dengan warga negara lainnya berdasarkan kesamaan hak. Dinas Sosial Daerah Istimewa Yogyakarta mencatat ada 25.050 disabilitas yang ada di Yogyakarta, atau sekitar 1 banding 146 jika dibandingkan dengan jumlah penduduk total Daerah Istimewa Yogyakarta. Badan Pusat Statistik pada tahun 2010 mencatat jumlah difabel di Indonesia ada sekitar 9.046.000 atau sekitar 4,74 persen dari jumlah keseluruhan penduduk Indonesia (Kusumaningrum, 2012) dan juga terdapat sekitar satu milyar atau $15 \%$ penduduk di dunia. Sering kali di Indonesia para penyandang disabilitas belum mendapatkan hak-hak yang seharusnya mereka dapatkan. Bahkan, dalam UU No.10 Tahun 2009 tentang kepariwisataan telah dicantumkan kesetaraan sebagai asas dari kepariwisataan. Namun, pada kenyataannya kesetaraan bagi penyandang difabel masih belum dapat terpenuhi secara maksimal dan merata.

Jumlah penyandang disabilitas yang begitu besar tersebut, tentunya dapat menjadi aset pangsa pasar yang cukup menggiurkan bagi Biro Perjalanan Wisata. Bagi wisatawan, membeli paket wisata yang dijual oleh biro perjalanan wisata akan lebih berharga, lebih efisien waktu, dan lebih nyaman dari membeli tiket wisata dan servis secara terpisah (Yong, 2016). Adanya Biro Perjalanan Wisata akan memudahkan para calon wisatawan dalam merancanakan perjalanan wisata mereka, serta akan membuat mereka lebih merasa aman dan nyaman selama kegiatan wisata ditempat yang jauh dan asing bagi mereka (Cohen dalam Yong, dkk., 2016). Saat ini, jumlah Biro Perjalanan wisata di Yogyakarta selalu mengalami peningkatan setiap tahunnya, Buku Statistik Kepariwisataan Daerah Istimewa Yogyakarta mencatat ada 602 Biro Perjalanan Wisata yang tersebar di Kabupaten atau Kota di Yogyakarta dengan rincian sebagai berikut: 


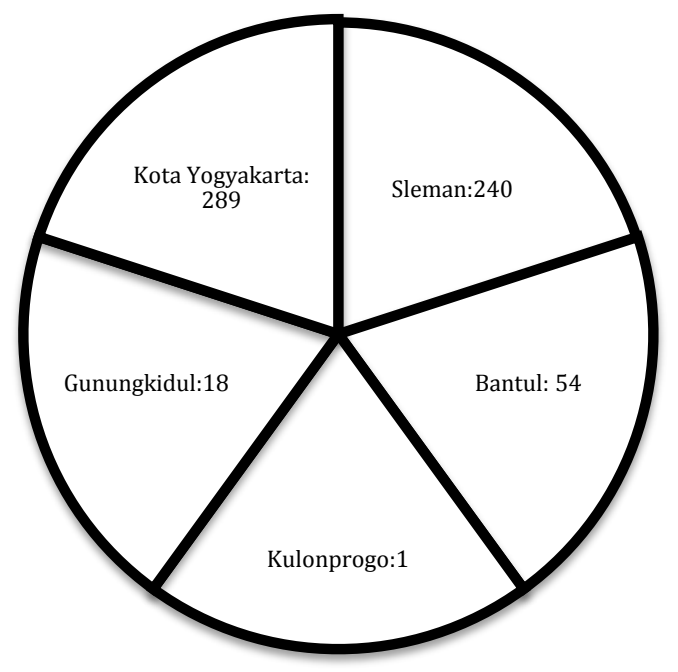

Gambar 1: Tabel Sebaran Biro Perjalanan Wisata di Yogyakarta

(Sumber: BPS, 2015)

Namun, hingga saat ini masih belum banyak Biro Perjalanan Wisata yang menyusun dan menjual paket wisata yang dikhususkan bagi para difabel, bahkan penulis telah melakukan pencarian di laman-laman Biro Perjalanan Wisata yang ada di Yogyakarta dan tidak menemukan satu pun Biro Perjalanan Wisata yang menyediakan paket wisata khusus bagi difabel.

Adanya penelitian ini diharapkan dapat menjadi evaluasi dan saran bagi pengelola Biro Perjalanan Wisata untuk lebih meningkatkan pelayanan mereka terhadap wisatawan difabel yang menggunakan jasa mereka. Ketika Biro Perjalanan Wisata sudah benar-benar mengimplementasikan amanah yang ada dalam peraturan yang disusun oleh pemerintah, maka pelayanan yang diberikan kepada konsumen juga akan menjadi lebih maksimal. Bagi penyandang disabilitas, diharapkan hak-hak akan kebutuhan mereka ketika melakukan kegiatan wisata akan dapat terpenuhi dan mereka akan nyaman ketika melakukan perjalanan wisata, sehingga mereka akan setara dengan orang-orang normal tanpa ada diskriminasi meskipun dengan kekurangan-kekurangan yang mereka miliki.

\section{LANDASAN TEORI}

Konsep barrier free tourism merupakan sebuah konsep tentang pariwisata pendidikan yang bisa di nikmati oleh semua orang termasuk difabel. Maka dari itu, tidak hanya orang-orang yang memiliki keadaan fisik dan psikologi normal saja yang boleh menikmati, tetapi juga untuk yang memiliki keterbatasan fisik maupun psikologinya (Leidner, 2008). Konsep tersebut membuat difabel untuk dapat menikmati kegiatan berwisata tanpa adanya halangan dengan segala kekurangan fisik ataupun mental yang mereka miliki. Mereka pun dapat merasakan dan menerima informasi yang ingin disampaikan pengelola tempat wisata sama seperti apa yang wisatawan pada umumnya dapat terima. Atas dasar tersebut, hak berwisata bagi difabel seharusnya dapat dipenuhi oleh pihakpihak yang berwenang atas hal tersebut.

Saat melakukan kegiatan berwisata, wisatawan difabel memiliki masalah yang membuat mereka tidak nyaman. Menurut Pagan (2012) mengutip pendapat Smith (1987) bahwa ketidaknyaman dan ketidakmampuan penyandang difabel untuk menikmati tempat wisata antara lain disebabkan oleh: a) intrinsic barriers atau keterbatasan yang dimiliki oleh para penyandang difabel; b) environmental 
barriers yaitu adanya keterbatasan fasilitas yang ada pada tempat pariwisata; dan c) interactive barriers termasuk di dalamnya kurangnya fasilitas untuk memudahkan komunikasi dengan para penyandang difabel. Ketidaknyamanan difabel dapat menghalangi mereka untuk memperoleh informasi serta pengetahuan yang ingin disampaikan ketika berada di suatu tempat wisata. Rasa tidak nyaman tersebut juga dapat membuat wisatawan difabel enggan untuk datang lagi ketempat wisata tersebut karena timbul perasaan tidak nyaman yang dapat berdampak pada keinginannya untuk bersedia datang ke tempat wisata itu lagi atau tidak.

\section{METODE}

Metode penelitian yang penulis gunakan dalam penelitian ini adalah metode kualitatif. Penulis mencari dan mengumpulkan data dengan cara studi literatur, wawancara, dan observasi. Melalui ketiga metode tersebut, penulis dapat memperoleh data yang lebih lengkap dan juga lebih mendalam.

Melalui studi pustaka/studi literatur, penulis mencari, membaca, dan menelaah data dan fakta dari sumber-sumber terpercaya terkait paket wisata untuk difabel. Sumber-sumber tersebut dapat diperoleh dari buku-buku yang ada di perpustakaan, jurnal-jurnal daring, dan berbagai sumber dari internet sehingga, data yang diperoleh merupakan data-data yang dapat dipertanggungjawabkan kebenarannya.

Wawancara dengan difabel juga penulis lakukan guna mengetahui apa yang mereka inginkan ketika melakukan kegiatan wisata. Hal ini dilakukan agar pihak Biro Perjalanan Wisata dapat lebih mengetahui dan memahami apa saja yang dibutuhkan oleh wisatawan disabilitas ketika mereka melakukan perjalanan wisata. Wawancara dengan difabel dilakukan dengan santai dan dengani caracara khusus agar informasi yang diperoleh menjadi lebih lengkap dan valid. Selain melakukan wawancara dengan difabel, penulis juga melakukan wawancara dengan Biro Perjalanan Wisata agar mendapatkan pendapat mereka tentang paket wisata khusus bagi difabel.

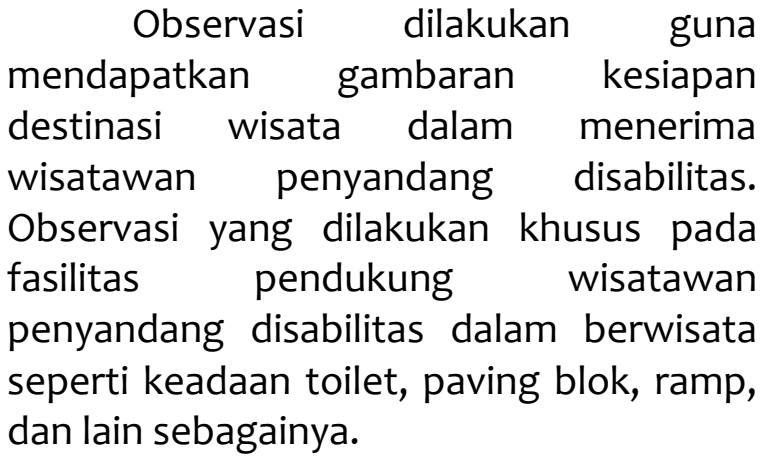

Penulis menggolongkan data yang diperoleh menjadi dua, yaitu data primer dan data sekunder. Data primer adalah data yang penulis dapatkan dan kumpulkan ketika melakukan wawancara mendalam dengan narasumber penyandang disabilitas, sedangkan data sekunder adalah data-data yang penulis dapatkan dari studi literatur, yaitu dari jurnal, buku, ataupun dari internet. Kedua jenis data tersebut akan membuat data yang diperoleh oleh penulis menjadi lebih kaya dan juga akan lebih lengkap.

Penelitian ini akan membandingkan temuan lapangan dengan kecocokan teori yang ada secara kualitatif. Selain itu, juga dilakukan koding terhadap hasil wawancara dilakukan dan kemudian dilanjutkan dengan mengelompokkan hasil koding tersebut ke dalam tema-tema yang telah ditentukan untuk kemudian dianalisis. 
Kemudian, untuk menarik kesimpulan dari data yang telah diperoleh di lapangan, penulis menggunakan metode verstehen, metode verstehen yaitu suatu metode untuk memahami objek penelitian melalui insight, einfeuhlung serta empati dalam menangkap dan memahami makna kebudayan manusia, nilai-nilai, simbolsimbol, pemikiran-pemikiran, serta kelakuan manusia yang memiliki sifat ganda (Kaelan, 2005: 72).

\section{Hasil dan Pembahasan}

maupun wisatawan mancanegara yang berkunjung ke Daerah Istimewa Yogyakarta setiap tahunnya terus mengalami peningkatan, jumlah wisatwan nusantara dari tahun ke tahun mengalami peningkatan yang cukup signifikan, pada tahun 2011 jumlah wisatawan nusantara yang mengunjungi Daerah Istimewa Yogyakarta berjumlah 1.438 .129 orang, jumlah tersebut mengalami kenaikan yang sangat tinggi pada tahun 2015 yang menyentuh angka 3.813.720 orang Badan Pusat Statistik, 2015).

Selain wisatawan nusantara, wisatawan mancanegara yang berkunjung ke Daerah Istimewa Yogyakarta setiap tahunnya terus mengalami peningkatan (Badan Pusat Statistik, 2015). Pada tahun 2011 jumlah wisatawan mancanegara yang berkunjung berjumlah 169.565 dan jumlah tersebut hampir berlipat ganda ada tahun 2015 dengan jumlah wisatawan yang datang mencapai 308.485. Kunjungan dari berbagai Negara tersebut juga terus meningkat setiap tahunnya, peningkatan jumlah kunjungan setiap Negara berkisar antara 8 hingga 13 persen. Jumlah tersebut cukup besar dan merupakan perkembangan jumlah wisatawan yang cukup signifikan dari tahun ke tahun.
Angka tersebut sudah termasuk wisatawan penyandang disabilitas, namun sangat disayangkan bahwa belum adanya pencatatan mengenai angka kunjungan difabel baik yang termasuk wisatawan domestik maupun mancanegara.

Ketika melakukan perjalanan wisata, adanya biro perjalanan wisata dapat memfasilitasi dan membuat wisatawan merasa lebih nyaman ketika berada di daerah yang baru mereka datang. Oleh karena itu, Biro Perjalanan Wisata menyusun paket wisata/paket tur untuk dipasarkan kepada calon wisatawan. Paket tur terdiri dari beberapa karakteristik, termasuk didalamnya jenisjenis komponen pelayanan seperti transportasi, akomodasi, makanan, dan atraksi (Yong dkk., 2016). Pembuatan paket wisata yang ramah untuk penyandang disabilitas, semua komponen tersebut juga harus ramah difabel. Pada tanggal 30 Maret tahun 2007 Indonesia telah berkomitmen untuk turut aktif memajukan hak-hak asasi difabel. Komitmen tersebut terlihat dari penandatanganan naskah Konvensi PBB tentang Hak-hak Asasi Penyandang Cacat dan Protokol Opsional terhadap Konvensi. Pasal 30 konvensi tersebut telah menyepakati bahwa penyandang cacat berhak berpartisipasi dalam kehidupan budaya, rekreasi, waktu luang, dan olahraga. Jadi, dapat disimpulkan bahwa berdasarkan komitmen yang telah dibangun tersebut tidak ada alasan bagi pemerintah Indonesia untuk tidak memberikan hak bagi wisatawan difabel agar mereka dapat melakukan kegiatan berwisata selayaknya wisatawan normal pada umumnya. Berbagai komponen paket perjalanan perancang dan perencana paket wisata juga harus 
mengupayakan untuk menjadikan ramah bagi penyandang disabilitas.

Aspek wisata yang ditawarkan di Yogyakarta mayoritas belum ramah terhadap wisatawan difabel (Rabbani, 2016), dari aspek-aspek tersebut Indonesia khususnya di Yogyakarta perlu mencontoh dari negara lain. Negara berikut adalah contoh yang sudah mempunyai aspekaspek dalam paket wisata yang sesuai dengan ketentuan yang berlaku bagi para penyandang disabilitas:

a. Australia

Australia merupakan sebuah Negara yang sudah cukup maju. Oleh karena itu, tidak heran jika kesadaran untuk memberikan hakhak bagi difabel telah terbentuk. Sebagai contoh, fasilitas umum yang ada di sana sudah dimodifikasi sedemikian rupa dan ditambah fasilitas-fasilitas penunjang bagi kaum difabel. Ketika hendak masuk ke dalam bus, biasanya calon penumpang dengan kursi roda akan kesulitan, namun di Australia hal tersebut bukan menjadi hambatan karena bus di Australia sudah dilengkapi dengan semacam jalur khusus berupa lempengan besi yang didesain sedemikian rupa secara portable untuk memudahkan penumpang untuk keluar dan masuk bus dari halte. Selain itu, sebuah pantai di Adelaide, untuk pertama kalinya menjadi pantai yang ramah terhadap tuna daksa, karena para wisatawan dengan kursi roda dapat dengan mudah untuk menjangkau pantai dan jalur yang dibuat khsus bagi tunadaksa tersebut juga portable sehingga tidak mengganggu kelestarian lingkungan yang ada di pantai (Videogeo, 2015).

b. Jepang

Jepang sudah terkenal sejak dulu sebagai negara dengan tingkat sumber daya manusia yang tinggi. Meskipun negara ini tidak terlalu luas, mereka benar-benar dapat mengolah dan mengoptimalkan sumber daya alam mereka yang sangat terbatas dengan memanfaatkan tingkat pendidikan dan inovasi-inovasi yang selalu mereka kembangkan. Selain itu, Jepang benar-benar memiliki kesadaran yang tinggi untuk dapat memberikan fasilitas-fasilitas yang dibutuhkan oleh setiap warganya tak terkecuali bagi kaum difabel. Hampir semua tempat-tempat umum bisa dibilang mempunyai fasilitas yang memadai untuk difabel. Bahkan, ada juga fasilitasfasilitas sederhana yang memberikan dampak besar dalam kenyamanan kaum difabel. Fasilitasfasilitas seperti toilet khusus difabel, paving block, kursi roda, tempat parkir khusus tunadaksa, dan juga ada bel khusus yang biasanya ada di supermarket yang berfungsi untuk memberikan sinyal kepada petugas agar membantu difabel yang dating. Selain pemerintah yang sangat memperhatikan dengan hak bagi difabel, masyarakat Jepang juga sudah terbiasa untuk menggunakan fasilitas-fasilitas umum yang sudah tersedia dimana fasilitas tersebut juga akan menunjang tingkat aksesibilitas destinasi wisata. 
Bisnis paket tur telah mendominasi pemasaran perjalanan internasional dalam satu dekade terakhir dan sekarang ini telah menjadi salah satu bisnis perjalanan terluas di dunia (Yong dkk., 2016). Melihat jumlah pasar yang besar tersebut dapat menjadi salah satu peluang bagi Biro Perjalanan Wisata yang ingin membuka jasa khusus untuk difabel. Namun, berdasarkan hasil dari data yang telah penulis temukan, sampai saat ini masih belum ada Biro Perjalanan Wisata yang merancang paket wisata khusus bagi penyandang disabilitas.

Daerah Istimewa Yogyakarta memiliki 602 biro perjalanan wisata (Buku Stastistik Pariwisata DIY , 2015). Jumlah tersebut tentunya cukup banyak untuk sebuah provinsi seluas $3.133 \mathrm{~km} 2$ dengan jumlah penduduk sebanyak 3.514.762 jiwa (Badan Pusat Statistik DIY, 2015). Hal tersebut dapat dijadikan sebagai sebuah indikasi bahwa Daerah Istimewa Yogyakarta merupakan daerah dengan tingkat perkembangan dan kegiatan wisata yang cukup tinggi. Penulis mengambil sampel 30 biro secara acak dari 602 total biro perjalanan wisata yang ada di Daerah Istimewa Yogyakarta. Kemudian dari 30 nama biro tersebut penulis mencari paket wisata yang ditawarkan oleh setiap biro melalui laman resmi dari biro tersebut dari internet. Semua sampel Biro Perjalanan Wisata yang penulis pilih tidak ada yang menyebutkan secara spesifik adanya paket wisata yang direncanakan dan dipasarkan bagi penyandang disabiltas. Penulis hanya menemukan sebuah organisasi dengan nama Difunic atau (difabel fun picnic) yang sejak tahun 2014 merancang paket wisata khusus bagi wisatawan dengan kebutuhan khusus, namun hanya untuk wisatawan tunawicara dan tunarungu. Namun, difunic tidak mempunyai laman resmi, dan hanya sempat aktif selama beberapa saat melalui media social twitter dan facebook pada tahun 2014 dan penulis tidak menemukan informasi yang akurat apakah saat ini organisasi tersebut masih menyediakan paket wisata khusus bagi "Orang dengan Kebutuhan Khusus".

Penulis juga melakukan wawancara dengan Gama Wisata, salah satu Biro Perjalanan Wisata di Yogyakarta. Pihak Gama Wisata menyatakan jika pihaknya hingga saat ini belum mempunyai paket wisata yang khusus dibuat untuk difabel, dan memang sampai saat ini belum pernah dilakukan pembahasan mengenai hal tersebut. Pihak Gama Wisata menyatakan jika mereka belum pernah mendapatkan konsumen difabel, pihaknya hanya pernah mendapatkan konsumen dengan kruk karena mengalami kecelakaan. Alasan Gama Wisata higga sampai saat ini belum menyusun paket wisata khusus bagi difabel adalah karena menurut mereka jumlah konsumen difabel kecil. Selain pertimbangan pasar yang kecil tersebut, pihak Gama Wisata juga mempertimbangkan aksesibilitas destinasi wisata, akomodasi, dan transportasi yang akan dipasarkan untuk difabel. Mereka menyatakan bahwa masih sangat sedikit destinasi yang bisa dijual untuk difabel, misalnya Candi Prambanan, hal tersebut dikarenakan Candi Prambanan sudah masuk dalam destinasi wisata internasional. Pihak Gama Wisata juga menyayangkan pemerintah yang kurang memperhatikan fasilitas-fasilitas yang telah dibuat bagi difabel, sebagai contoh adalah guiding block yang ada di Malioboro yang kurang diperhatikan dan banyak yang tertutupi oleh warung-warung yang dibangun disana. Menurut pihak Gama 
Wisata, aksesibilitas akomodasi misalnya hotel di Yogyakarta sudah banyak yang ramah terhadap difabel, namun transportasi yang digunakan untuk mengantarkan difabel ketika melakukan perjalanan wisata juga masih belum ramah terhadap difabel. Karena alasan tersebut, Gama Wisata belum memiliki rencana untuk membuat paket wisata bagi difabel.

Biro-biro tersebut cenderung lebih menitikberatkan paket wisata berdasarkan destinasi yang hendak dituju, sedangkan seharusnya kebutuhan difabel bukan hanya ketika di destinasi/atraksi wisata saja, namun juga selama penyandang difabel tersebut melakukan perjalanan wisata, dari semua aspek seperti transportasi, dan akomodasi juga harus ramah terhadap difabel. Setiap difabel membutuhkan fasilitas-fasilitas khusus untuk dapat menunjang kemandirian mereka ketika berwisata, fasilitas yang dibutuhkan oleh difabel ketika melakukan perlajanan wisata, dalam penelitian ini penulis mengambil contoh empat jenis difabel, yaitu: tunarungu, tunagrahita, tunanetra, dan tunadaksa. Tunarungu adalah difabel dengan kekurangan pada pendengaran, tunagrahita adalah difabel dengan kekurangan mental, tunanetra/low vision adalah difabel dengan kekurangan penglihatan serta tunadaksa adalah difabel dengan kekurangan/cacat tubuh. Fasilitas yang harus dipenuhi oleh Biro perjalanan wisata bagi berbagai jenis difabel tersebut antara lain:

a. Tunarungu, fasilitas yang dibutuhkan oleh tunarungu berdasarkan wawancara yang telah penulis lakukan adalah teks penjelasan dan pemandu khusus. Wisatawan tunarungu membutuhkan teks penjelasan pada setiap atraksi yang dikunjungi, fasilitas tersebut diperlukan agar wisatawan dapat memahami dengan jelas maksud atau pesan yang ingin disampaikan pada setiap atraksi wisata. Pemandu khusus diperlukan bagi tunarungu, yaitu pemandu yang menguasai bahasa isyarat, karena jika tanpa bahasa isyarat wisatawan tunarungu akan kesulitan dalam melakukan perjalalanan wisata karena mereka sulit berkomunikasi tanpa bahasa isyarat.

b. Tunagrahita, fasilitas yang dibutuhkan oleh tunagrahita adalah atraksi yang menyenangkan dan mudah dipahami. Selain atraksi, setiap aspek yang diberikan oleh Biro Perjalanan Wisata seperti akomodasi, traansportasi dan lain-lain harus mudah dipahami serta lebih sederhana. Berdasarkan wawancara yang dilakukan oleh penulis hal tersebut harus dilakukan karena tunagrahita memiliki keterbatasan mental sehingga mereka cukup sulit untuk memahami dan mengontrol emosi mereka, apalagi ketika mereka sudah merasa kelelahan maka akan lebih sulit ketika melakukan perjalanan wisata. Paket wisata yang ditawarkan akan lebih baik jika tidak memerlukan perjalanan jauh.

c. Tunanetra, fasilitas yang dibutuhkan oleh tunanetra adalah guiding block, huruf braile, dan audio. Guiding block dibutuhkan oleh tunanetra yang menggunakan tongkat sebagai alat bantu mereka untuk menentukan arah. Huruf braile dibutuhkan oleh tunanetra ketika membaca teks menggunakan tangan mereka, didalam paket wisata hal ini harus sangat diperhatikan agar wisatawan tunanetra dapat memahami penjelasan dari setiap atraksi dan lain- 
lain. Audio disini dapat berupa penjelasan ketika di wahana/atraksi bisa juga berupa panduan alur perjalanan ketika melakukan kegiatan wisata, karena pengunjung tunanetra akan kesulitan untuk memahami alur ketika di tempat yang baru mereka datangi.

d. Tunadaksa, fasilitas khusus yang dibutuhkan oleh tunadaksa ketika melakukan perjalanan wisata, antara lain ramp, toilet khusus untuk tunadaksa, dan juga tangga dengan pegangan. Ramp adalah jalur bidang miring yang diperuntukkan oleh difabel yang menggunakan kursi roda, ramp sangat penting bagi tunadaksa karena tanpa ramp tunadaksa akan sangat kesulitan untuk menjangkau tempat yang lebih tinggi. Toilet khusus bagi tunadaksa dibutuhkan karena jika hanya toilet biasa tanpa ada pegangan dan ukuran yang tidak cukup luas untuk dilewati kursi roda maka akan menyulitkan bagi tunadaksa. Sementara itu, pegangan yang ada di tangga adalah untuk keamanan dan kenyamanan bagi tunadaksa.

Sebenarnya Indonesia telah
mengatur tentang Kegiatan
Kepariwisataan dalam Undang-Undang
Nomor 10 tahun 2009. Undang-Undang
tersebut menyebutkan bahwa negara telah
menjamin hak berwisata bagi semua orang
termasuk difabel sehingga difabel juga
memiliki hak yang sama untuk berwisata.
Hak untuk berwisata tersebut juga
termasuk didalamnya adalah tentang
kenyamanan dan keterjangkauan bagi
wisatawan difabel. Pembuatan suatu objek
wisata menjadi yang nyaman untuk difabel
diperlukan adanya fasilitas-fasilitas khusus

tentunya. Fasilitas-fasilitas tersebut juga telah diatur dalam Peraturan Menteri Pekerjaan Umum Nomor 30 tahun 2006 tentang Pedoman Teknis Fasilitas dan Aksesibilitas pada Bangunan Gedung dan Lingkungan telah menjelaskan standart fasilitas minimal yang ada pada sebuah bangunan.

Namun, implementasi dari kebijakan tersebut masih sangat minim. Fasilitas minimal yang dimaksud tersebut meliputi: Ukuran Dasar Ruang, Jalur Pedestrian, Jalur Pemandu, Area Parkir, Pintu, Ramp, Tangga, Lift, Lift tangga, Toilet, Pancuran, Wastafel, Telepon, Perlengkapan dan Peralatan Kontrol, Perabot, Rambu dan Marka. Adanya fasilitas-fasilitas tersebut diharapkan difabel akan merasa nyaman dan aman ketika di tempat-tempat umum serta tidak ada kesenjangan antara difabel dengan masyarakat pada umumnya.

\section{Kesiapan Destinasi Wisata Mewujudkan Pariwisata Inklusi}

Penulis juga melakukan penelitian terhadap beberapa destinasi wisata unggulan yang ada di Yogyakarta, dalam hal ini penulis memilih Taman Pintar dan Keraton Yogyakarta. Penulis memilih Keraton Yogyakarta karena tempat ini menjadi salah satu tujuan utama wisata budaya Yogyakarta, sehingga setiap tahunnya dikunjungi oleh ratusan ribu wisatawan mancanegara dan nusantara.

\section{A. Taman Pintar}

Salah satu objek daya tarik wisata yang menjadi unggulan di Yogyakarta adalah Taman Pintar. Taman Pintar berlokasi di Jalan Panembahan Senopati nomor 1-3, 
Yogyakarta. Taman Pintar sesuai namanya bertujuan sebagai tempat wisata yang berbasiskan oleh pendidikan. Taman Pintar ini memiliki visi yakni menjadi tempat wisata berbasis pendidikan science terbesar di Asia Tenggara (Profil, n.d, para.1). Taman Pintar sebagai edu-park terbesar di Asia Tenggara memang mempunyai cukup banyak wahana didalamnya. Wahanawahana tersebut lebih menitik beratkan terhadap pendidikan kepada anak-anak, tidak heran jika kebanyakan wisatawan yang mengnjungi Taman Pintar adalah anak-anak usia sekolah. Selain itu, terdapat sekitar 948.163 pengunjung yang datang ke sana pada tahun 2015 (Badan Pusat Statistik, 2015). Besarnya jumlah itu menunjukan bahwa Taman Pintar merupakan salah satu destinasi wisata favorit yang banyak dikunjungi wisatawan. Dengan animo dari masyarawat untuk berwisata ke Taman Pintar yang begitu besar, sudah menjadi keharusan bagi penhelola objek wisata tersebut untuk meningkatkan pelayanan dan fasilitas yang ada disana.

Namun pada kenyataannya, keadaan di Taman Pintar bisa dikatakan belum sesuai dengan ekspektasi yang diharapkan sebagai edu-park terbesar yang ada di Asia Tenggara. Berdasarkan fakta di lapangan masih terdapat fasilitas yang belum tersedia dan beberapa fasilitas yang tersedia pun belum sesuai standart minimal yang telah ditetapkan oleh pemerintah dalam peraturan perundang-undangan.

Ketidaksesuaian fasilitas
tersebut mengakibatkan
ketidaknyamanan saat berwisata.
Wisatawan yang datang, apalagi
difabel akan mengalami kendala
ketika menikmati setiap wahana
yang ada disana, hal tersebut
membuat pesan edukasi yang
menjadi tujuan dari taman pintar
tidak tersalurkan seperti yang
diharapkan sehingga jumlah
repeater wisatawan difabel menjadi
tidak banyak. Berdasarkan
observasi yang kami lakukan di
lapangan, beberapa contoh fasilitas
di Taman Pintar yang masih tidak
sesuai denganketetapan yang telah
ditentukan oleh pemerintah, antara
lain:

a. Ramp; ketika berkunjung ke Taman Pintar memang sudah terdapat fasilitas ramp yang dibuat untuk memudahkan aksesibilitas bagi penyandang disabilitas yang menggunakan kursi roda, namun beberapa ramp yang dibuat di Taman Pintar masih ada yang terlalu curam, landasan yang terlalu dekat dengan tembok, dan juga ramp tanpa jalur landai untuk istirahat seperti ramp yang menghubungkan antara lantai satu dengan lantai dua.

b. Lift; lift yang disediakan khusus untuk tunadaksa masih terlalu sempit, sehingga ketika penyandang disabilitas dengan kursi roda memasuki lift tersebut akan cukup susah. Selain itu, lift khusus difabel tersebut justru seperti disembunyikan oleh pihak 
pengelola, sehingga jika ada yang ingin menggunakan harus meminta bantuan pada petugas disana agar mengantarkan menuju lift tersebut.

\section{B. Keraton Yogyakarta}

Keraton Yogyakarta setiap tahunnya dikunjungi oleh ratusan ribu wisatawan domestik dan mancanegara. Jumlah wisatawan yang begitu besar tersebut pada kenyataannya hak dari wisatawan ketika berkunjung ke Keraton Yogyakarta belum sepenuhnya terpenuhi, salah satunya adalah hak bagi pengunjung difabel. Penulis telah melakukan observasi lapangan dan juga wawancara kepada pengelola Keraton Yogyakarta. Berdasarkan observasi yang dilakukan oleh penulis, banyak fasilitas bagi difabel yang belum diadakan dan dikelola dengan baik. Contohnya adalah sebagai berikut:

a. Ramp, ramp yang ada di Keraton Yogyakarta dinilai sudah tidak cukup kuat, karena ketika penulis melakukan pengujian, ramp tersebut melengkung dan hal tersebut tentunya sangat membahayakan bagi pengunjung yang menggunakan kursi roda.

b. Toilet, Keraton Yogyakarta juga belum mempunyai toilet khusus bagi pengunjung yang menggunakan kursi roda. Padahal toilet menjadi salah satu fasilitas utama yang dibutuhkan oleh wisatawan ketika berkunjung ke sebuah objek wisata.
Pihak dari Keraton Yogyakarta juga menyatakan alasan bahwa mengapa fasilitas-fasilitas khusus bagi pengunjung difabel hingga saat ini belum ada adalah karena jumlah pengunjung difabel yang berkunjung belum signifikan, bahkan mereka juga menyatakan pembangunan ramp yang ada di Keraton adalah untuk menyambut kedatangan Gus Dur dan bukan untuk wisatawan tunadaksa.

\section{Kesimpulan}

Difabel atau orang dengan kebutuhan khusus sering menjadi pihak yang termarjinalkan dalam masyarakat. Sering kali keberadaan mereka kurang tersentuh oleh pihak-pihak yang seharusnya bertanggungjawab dan mempunyai wewenang untuk mewujudkan hak-hak mereka juga belum bekerja secara maksimal. Berdasarkan data dari Badan Pusat Statistik pada tahun 2015 di Yogyakarta terdapat 25 ribu lebih orang dengan kebutuhan khusus. Seharusnya difabel mempunyai hak-hak yang harus dipenuhi oleh pemerintah tidak terkecuali hak-hak para difabel ketika mereka melakukan perjalanan wisata. Khusus dalam pariwisata, berdasarkan UU No. 10 tahun 2009 sudah dijelaskan bahwa difabel memiliki hak-hak yang sama untuk dapat berwisata seperti masyarakat pada umumnya.

Pihak yang seharusnya dapat berperan besar, tidak terkecuali Biro Perjalanan Wisata, dalam mewujudkan pariwisata yang ramah difabel hingga saat ini belum memberikan pelayanan yang maksimal bagi penyandang disabilitas. 
Daerah Istimewa Yogyakarta memiliki total 602 Biro Perjalanan Wisata, namun dari 30 sampel yang penulis pilih secara acak dan penulis tidak menemukan Biro Perjalanan Wisata yang menjual paket wisata bagi calon wisatawan penyandang disabilitas. Berdasarkan data yang diperoleh tersebut, penulis dapat menyatakan bahwa Biro Perjalanan Wisata yang ada di Daerah Istimewa Yogyakarta belum dapat menyusun dan menjual paket wisata yang ramah bagi wisatawan difabel.

Jika ditelaah secara lebih dalam, potensi dari jumlah calon wisatawan dengan kebutuhan khusus yang berkunjung ke Yogyakarta cukup besar. Hal tersebut seharusnya dapat dimanfaatkan secara lebih optimal oleh Biro Perjalalanan Wisata di Yogyakarta untuk mendapatkan keuntungan. Namun, sampai saat ini Biro Perjaalanan Wisata yang ada di Yogyakarta belum memberikan pelayanan yang optimal dalam menyusun paket wisata bagi orang dengan kebutuhan khusus atau difabel.

\section{Daftar Pustaka}

Badan Pusat Statistik. 2016. Statistik Kepariwisataan Daerah Istimewa Yogyakarta 2015. Yogyakarta:BPS

Chen, Yong, Schuckert, Markus, Song, Haiyan, Chon, Kaye. 2016. Why Can Package Tours Hurt Tourists? Evidence from China's Tourism Demand in Hong Kong. Journal of Travel Research, 1-13. DOI. 10.1177/0047287515612597

Ethical:Barrier Free Tourism. n.d. [Review] Diakses dari https://www.tourismreview.com/travel-tourism-magazineethical-barrier-free-tourismcategory 477

Kaelan. 2005. Metode Penelitian Kualitatif. Yogyakarta: Paradigma.
Kusumaningrum, Haritsah. 2012. Aksesibilitas Untuk Pengunjung Difabel Di Obyek Wisata Museum Benteng Vredeberg. Tesis tidak dipublikasikan, S2 Magister Kajian Pariwisata, Universitas Gajah Mada.

Paga'n, Ricardo. 2012. Time Allocation in Tourism for People with Disabilities. Annals of Tourism Research Vol 39 (3), 1514-1537. Diakses dari https://ac.elscdn.com/S0160738312000540/1-s2.0S0160738312000540main.pdf?_tid=34a7a7ea-a418-11e7agodo0000aacb362\&acdnat $=1506581133$ ao fogd2d1f7b67dogeb22b35eef52b55

Profil, n.d. diakses dari www.tamanpintar.com. http://www.tamanpintar.com/profiltaman-pintar/. Diakses pada 12 Juni 2017 Rabbani, Ikrar G. Belum Semua Objek Wisata Ramah Difabel. Tribun Jogja, 26 Desember 2016

Republik Indonesia. 2006. Peraturan Menteri Pekerjaan Umum Nomor 30 tahun 2006 tentang Pedoman Teknis Fasilitas dan Aksesibilitas pada Bangunan Gedung dan Lingkungan. Jakarta:Kementerian Pekerjaan Umum 2009. Undang-Undang No. 10 Tahun 2009 tentang Kepariwisataan. Jakarta: Sekretariat Kabinet. . 2016. Undang-Undang No. 8 Tahun 2016 Tentang Penyandang Disabilitas. Jakarta: Sekretariat Negara

Viodeogo, Yanuarius (2015, Mei 19). Kota Melbourne Ramah untuk Kaum Difabel. Diakses dari http://traveling.bisnis.com/read/201505 19/224/434915/kota-melbourne-ramahuntuk-kaum-difabel. Diakses pada 12 Juni 2017. 
F Handoyo, AN Sholihah, A Novitariasari, AF Hani, QP Firdausa, H Rahayuningsih 